\title{
Candidate genes for monitoring hydrogen peroxide resistance in the salmon louse, Lepeophtheirus salmonis
}

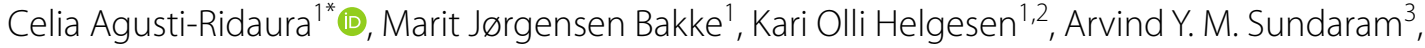
Sigrid Jørgensen Bakke ${ }^{4}$, Kiranpreet Kaur ${ }^{1,5}$ and Tor Einar Horsberg ${ }^{1}$

\begin{abstract}
Background: Hydrogen peroxide $\left(\mathrm{H}_{2} \mathrm{O}_{2}\right)$ is one of the delousing agents used to control sea lice infestations in salmonid aquaculture. However, some Lepeophtheirus salmonis populations have developed resistance towards $\mathrm{H}_{2} \mathrm{O}_{2}$. An increased gene expression and activity of catalase, an enzyme that breaks down $\mathrm{H}_{2} \mathrm{O}_{2}$, have been detected in resistant lice, being therefore introduced as a resistance marker in the salmon industry. In the present study the aim was to validate the use of catalase expression as a marker and to identify new candidate genes as additional markers to catalase, related to $\mathrm{H}_{2} \mathrm{O}_{2}$ resistance in L. salmonis.
\end{abstract}

Methods: A sensitive and an $\mathrm{H}_{2} \mathrm{O}_{2}$ resistant laboratory strain ( $\mathrm{PO}$ generation, not exposed to $\mathrm{H}_{2} \mathrm{O}_{2}$ for several years) were batch crossed to generate a cohort with a wide range of $\mathrm{H}_{2} \mathrm{O}_{2}$ sensitivities ( $F 2$ generation). F2 adult females were then exposed to $\mathrm{H}_{2} \mathrm{O}_{2}$ to separate sensitive and resistant individuals. Those F2 lice, the PO lice and field-collected resistant lice (exposed to $\mathrm{H}_{2} \mathrm{O}_{2}$ in the field) were used in an RNA sequencing study.

Results: Catalase was upregulated in resistant lice exposed to $\mathrm{H}_{2} \mathrm{O}_{2}$ compared to sensitive lice. This was, however, not the case for unexposed resistant PO lice. Several other genes were found differentially expressed between sensitive and resistant lice, but most of them seemed to be related to $\mathrm{H}_{2} \mathrm{O}_{2}$ exposure. However, five genes were consistently up- or downregulated in the resistant lice independent of exposure history. The upregulated genes were: one gene in the DNA polymerase family, one gene encoding a Nesprin-like protein and an unannotated gene encoding a small protein. The downregulated genes encoded endoplasmic reticulum resident protein 29 and an aquaporin (Glp1_v2).

Conclusions: Catalase expression seems to be induced by $\mathrm{H}_{2} \mathrm{O}_{2}$ exposure, since it was not upregulated in unexposed resistant lice. This may pose a challenge for its use as a resistance marker. The five new genes associated with resistance are put forward as complementary candidate genes. The most promising was Glp1_v2, an aquaglyceroporin that may serve as a passing channel for $\mathrm{H}_{2} \mathrm{O}_{2}$. Lower channel number can reduce the influx or distribution of $\mathrm{H}_{2} \mathrm{O}_{2}$ in the salmon louse, being directly involved in the resistance mechanism.

Keywords: $\mathrm{H}_{2} \mathrm{O}_{2}$ resistance markers, Sea lice, RNAseq, Catalase, Aquaporin

\footnotetext{
*Correspondence: celia.agusti@nmbu.no; agusti.celia@gmail.com

${ }^{1}$ Faculty of Veterinary Medicine, Sea Lice Research Centre, Norwegian University of Life Sciences, 1433 Aas, Norway

Full list of author information is available at the end of the article
}

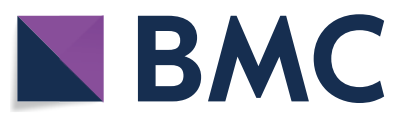

(c) The Author(s) 2020. This article is licensed under a Creative Commons Attribution 4.0 International License, which permits use, sharing, adaptation, distribution and reproduction in any medium or format, as long as you give appropriate credit to the original author(s) and the source, provide a link to the Creative Commons licence, and indicate if changes were made. The images or other third party material in this article are included in the article's Creative Commons licence, unless indicated otherwise in a credit line to the material. If material is not included in the article's Creative Commons licence and your intended use is not permitted by statutory regulation or exceeds the permitted use, you will need to obtain permission directly from the copyright holder. To view a copy of this licence, visit http://creativeco mmons.org/licenses/by/4.0/. The Creative Commons Public Domain Dedication waiver (http://creativecommons.org/publicdomain/ zero/1.0/) applies to the data made available in this article, unless otherwise stated in a credit line to the data. 


\section{Background}

The salmon louse Lepeophtheirus salmonis (Copepoda: Caligidae) is one of the most important parasitic problems in the Northern hemisphere salmonid aquaculture $[1,2]$. It also represents a hazard for wild salmonids [3]. Control of the parasite has historically been based on anti-lice chemicals. However, overuse, in order to keep the louse numbers below the maximum permitted levels in Norway, has led to the development of reduced sensitivity towards most of the available chemical treatments $[1,2]$. Alternative mechanical and preventive methods have been developed to avoid this problem [3]. Currently, salmon lice control in Norway is based on a combination of preventive, mechanical and chemical delousing methods, as well as extensive monitoring of lice infestation and lice sensitivity to anti-lice treatments $[2,4-6]$.

Hydrogen peroxide $\left(\mathrm{H}_{2} \mathrm{O}_{2}\right)$ is one of the anti-lice compounds used for controlling salmon lice infestations [7]. It was used between 1993 and 1997 in Norway as a delousing agent, but new chemicals showing better efficacy and better safety margins for fish and farm personnel replaced it. In 2009, $\mathrm{H}_{2} \mathrm{O}_{2}$ was reintroduced in the Norwegian salmonid farming industry [8], when reduced efficacy of other chemical treatments was identified [1]. $\mathrm{H}_{2} \mathrm{O}_{2}$ is also used in Norwegian aquaculture for treating the amoebic gill disease caused by Paramoeba perurans [9]. As a result, there was a large increase in the use of this compound in the period 2014-2016 [10]. In 2015, reports on reduced sensitivity towards $\mathrm{H}_{2} \mathrm{O}_{2}$ in salmon lice were published [11], and the use of this compound was limited due to reduced efficacy. Bioassays on parasites collected in the field, as well as on their descendants, showed a considerable increase in the $\mathrm{EC}_{50}$ values (the compound concentration affecting $50 \%$ of the parasites), confirming higher tolerance to $\mathrm{H}_{2} \mathrm{O}_{2}$ in these cohorts compared to parasites from a susceptible laboratory reared strain [11]. $\mathrm{H}_{2} \mathrm{O}_{2}$ resistance in salmon lice is an important issue not only in Norway, but also in other salmon producing countries such as Scotland [12].

In biological systems, $\mathrm{H}_{2} \mathrm{O}_{2}$ is a naturally occurring reactive oxygen species molecule with cytotoxic effects. It has an important function as a signalling molecule that affects a variety of processes, e.g. immune responses [13]. Several enzymes are involved in the production and regulation of endogenous $\mathrm{H}_{2} \mathrm{O}_{2}$. Therefore, it was not surprising to discover that catalase was involved in the mechanism providing protection to the salmon lice against $\mathrm{H}_{2} \mathrm{O}_{2}$ exposure, as this enzyme catalyses the breakdown of $\mathrm{H}_{2} \mathrm{O}_{2}$ to $\mathrm{H}_{2} \mathrm{O}$ and $\mathrm{O}_{2}$. It was shown that resistant salmon lice had higher catalase gene expression and catalase enzymatic activity compared to sensitive lice [14]. The expression level of catalase was therefore introduced as a $\mathrm{H}_{2} \mathrm{O}_{2}$ resistance marker in the salmon industry [15]. An accurate time-space monitoring of the sensitivity level of salmon lice to $\mathrm{H}_{2} \mathrm{O}_{2}$ is necessary in order to apply correct control measures. In addition, to know beforehand if the parasites are resistant is highly beneficial in order to avoid the economical, fish welfare and environmental costs of an unsuccessful treatment. Molecular methods have been demonstrated as powerful tools for monitoring the sensitivity of sea lice to chemicals $[16,17]$, hence the importance of improving and developing such tools for all anti-lice compounds.

In addition to the catalase enzyme, it would be expected that the lice possess additional mechanisms to protect themselves against high levels of $\mathrm{H}_{2} \mathrm{O}_{2}$ [12]. RNA sequencing (RNAseq) is a powerful tool to compare gene expression (as number of transcripts) between selected groups, for all genes simultaneously. This allows for the identification of genes potentially associated with such mechanisms as resistance.

The aims of the present study were to (i) validate the use of the commercially available $\mathrm{H}_{2} \mathrm{O}_{2}$ resistance marker (catalase expression), (ii) identify new candidate genes for developing molecular markers based on differential expression, and (iii) use the annotation of the candidate genes to put forward new hypotheses on the resistance mechanism for $\mathrm{H}_{2} \mathrm{O}_{2}$ in salmon lice.

\section{Methods}

\section{Salmon louse strains}

Two well-characterized laboratory L. salmonis strains were used in this study: Ls A, sensitive to all anti-salmon lice compounds used in Norway (tested by bioassays); and Ls V, resistant to azamethiphos, deltamethrin, emamectin benzoate and hydrogen peroxide (field reports and bioassays). Ls A was a strain originally collected on a fish farm in the northern part of Norway in 2011. Ls V was collected in October 2013, from a fish farm in mid-Norway with high anti-louse treatment pressure and reported diminished $\mathrm{H}_{2} \mathrm{O}_{2}$ treatment efficacy. A total of 14 anti-louse chemical treatments were performed from August 2012 to September 2013 in that farm: $6 \mathrm{H}_{2} \mathrm{O}_{2}$ treatments (up until one month before the lice collection); 6 combined treatments with deltamethrin and azamethiphos; 1 treatment with diflubenzuron; and 1 with emamectin benzoate. The Ls V-2013 samples referred to in the current study were the original field samples of this strain. Ls A and Ls V strains were reared in continuous cultures at the research facilities of Solbergstrand (The Norwegian Institute for Water Research, NIVA, Drøbak, Norway), as described by Hamre et al. [18]. Both strains were maintained without any selection by medicinal compounds. 


\section{Crossing experiment and bioassays}

In order to obtain lice samples from the same generation and with a range of $\mathrm{H}_{2} \mathrm{O}_{2}$ sensitivities, a batch crossing experiment was designed. The experiment was performed as described by Bakke et al. [19] in 2015. Briefly, 2 Atlantic salmon (1 fish per tank) were infested with approximately 50 Ls A copepodids each and another 2 fish (1 fish per tank) with the same number of Ls V copepodids to produce the parental generation (P0). All salmon lice were collected from all fish when the lice were in the preadult II stage, before mating occurred. Then 10 pre-adult II Ls A females and 10 pre-adult II Ls V males from the P0 generation were distributed equally on 2 fish kept in individual tanks, to produce the F1 generation of family group 1 . The same procedure was used to produce the F1 generation of family group 2, only with opposite sex from each strain, i.e. females from Ls $\mathrm{V}$ and males from Ls A. All P0 lice from both family groups were preserved in RNAlater (Sigma-Aldrich, MO, USA) after removal of the egg strings which were set aside to hatch. After $\sim 24 \mathrm{~h}$ at room temperature, the preserved samples were stored at $-80{ }^{\circ} \mathrm{C}$. Four fish were infested with copepodids from the F1 generation: 2 fish with copepodids from the family group 1 and 2 fish with copepodids from the family group 2. The lice developed to the adult stage, mated, and egg strings for the F2 generation were collected. Approximately 500 copepodids from each of the family groups 1 and 2 (F2) were used for infestation of 8 Atlantic salmon for each family group, with the two family groups separated in different tanks.

F2 parasites were selected for sensitivity towards $\mathrm{H}_{2} \mathrm{O}_{2}$ (Interox Paramove 50, $\mathrm{H}_{2} \mathrm{O}_{2} 50 \%$, w/w; Solvay Chemicals, Brussels, Belgium) when they reached the adult stage. The selection was performed in vitro using two-dose bioassays at the Faculty of Veterinary Medicine, NMBU (University of Life Sciences, Oslo, Norway), starting within $6 \mathrm{~h}$ after sampling. All exposures were done in $1 \mathrm{l}$ glass bottles held at $10-12{ }^{\circ} \mathrm{C}$ with constant aeration. The

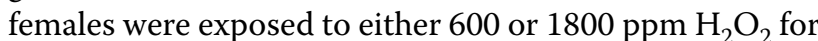
$30 \mathrm{~min}$ and the results were recorded immediately following exposure [11]. Control groups not exposed to $\mathrm{H}_{2} \mathrm{O}_{2}$ were included to check the general performance of the parasites. Parasites affected/immobilized at the lowest $\mathrm{H}_{2} \mathrm{O}_{2}$ concentration were considered sensitive, whereas parasites that were not visibly affected at the highest concentration were considered resistant. Lice were classified as affected when they were unable to attach to the container wall (lice could show weak swimming pattern, be partially or completely immobilized at the bottom of the container or float at the surface). Immediately after exposure and recording of the immobilization rate, lice were fixed in RNAlater and kept at $-80{ }^{\circ} \mathrm{C}$ following $\sim 24 \mathrm{~h}$ at room temperature. Results were expressed as number and percentages of affected lice. A Chi-square test was used to test differences between family groups (statistically significance was assumed when $P<0.05$ ). $\mathrm{H}_{2} \mathrm{O}_{2}$-sensitive and -resistant $\mathrm{F} 2$ adult females (named F2-S and F2-R, respectively) were used in the RNAseq analysis.

\section{Transcriptome analysis: samples and RNA extraction} In total, 36 adult female lice were enrolled in the transcriptome analysis. Details on their origin and group affiliation are given in Table 1. Total RNA was extracted from the individual adult females using a Trizol (Ambion, Life Technologies Thermo Fisher Scientific, Waltham, Massachusetts, USA) protocol combined with RNeasy Mini kit for animal tissues (Qiagen, Venlo, The Netherlands) (1 individual per extraction). Louse tissues were disrupted and homogenized in $1 \mathrm{ml}$ Trizol using TissueLyser MM 301 (Qiagen Retsch, Venlo, The Netherlands) and one stainless steel bead of $5 \mathrm{~mm}$ diameter (Qiagen). After mixing with $0.2 \mathrm{ml}$ of chloroform and a centrifugation step, the aqueous phase was transferred to a new vial and mixed with

Table 1 Data on the 36 samples used in the RNAseq study

\begin{tabular}{|c|c|c|}
\hline Group & $n$ & Description \\
\hline Ls A-2013 & 4 & $\begin{array}{l}\text { Laboratory strain, sensitive to all delousing chemicals. Collected in northern Norway in 2011. Sixth generation. Not exposed to delous- } \\
\text { ing chemicals during cultivation of any generation }\end{array}$ \\
\hline Ls V-2013 & 5 & Field strain, resistant to azamethiphos, deltamethrin, emamectin benzoate and hydrogen peroxide. Collected in mid-Norway in 2013 \\
\hline Ls A-PO & 3 & Laboratory strain. 12th generation of Ls A (sensitive). Not exposed to delousing chemicals during cultivation of any generation \\
\hline LS V-PO & 4 & Laboratory strain. Sixth generation of Ls V (resistant). Not exposed to delousing chemicals during cultivation of any generation \\
\hline Ls F2-S & 8 & $\begin{array}{l}\text { Second generation after crossing of Ls A-PO and Ls V-PO, affected by } 600 \text { ppm } \mathrm{H}_{2} \mathrm{O}_{2} \text { for } 30 \text { min (sensitive). Three lice from family group } 1 \\
\text { and five lice from family group } 2\end{array}$ \\
\hline Ls F2-R & 12 & $\begin{array}{l}\text { Second generation after crossing of Ls A-PO and Ls V-P0, unaffected by } 1800 \text { ppm } \mathrm{H}_{2} \mathrm{O}_{2} \text { for } 30 \text { min (resistant). Seven lice from family } \\
\text { group } 1 \text { and five lice from family group } 2\end{array}$ \\
\hline
\end{tabular}

Notes: All adult female lice. Family group 1: females from the sensitive Ls A strain were crossed with males from the $\mathrm{H}_{2} \mathrm{O}_{2}$-resistant $\mathrm{Ls} V$ strain in the P0 generation. Family group 2: males from the sensitive Ls A strain were crossed with females from the Ls $V$ strain

Abbreviation: $n$, sample size 
one volume of $70 \%$ ethanol. Total RNA was then isolated with RNeasy spin columns following the manufacturer's protocol. Genomic DNA was removed from the extracted RNA $(10 \mu \mathrm{g})$ with Turbo DNA-free kit (TURBO ${ }^{\mathrm{TM}}$ DNase Treatment and Removal Reagents; Ambion, Life Technologies Thermo Fisher Scientific). Subsequently, the RNA was cleaned and concentrated with RNA Clean \& Concentrator $^{\mathrm{TM}}-5$ kit (Zymo Research, CA, USA). The RNA was quantified with a ND-1000 Spectrophotometer (Thermo Fisher Scientific) and the quality was checked with a 2100 Bioanalyzer instrument (Agilent Technologies, CA, USA) and the Agilent RNA 6000 Nano kit.

\section{Transcriptome analysis: RNAseq}

Total RNA samples were used for library preparation and Illumina sequencing at the Norwegian Sequencing Centre (Oslo, Norway). Thirty-six RNAseq libraries (1 per individual louse), each with unique index barcodes, were prepared using the TruSeq Stranded total RNA library preparation Kit v2 (Illumina, CA, USA) following the manufacturer's protocol including the polyA enrichment step. Libraries were pooled together and sequenced on NextSeq500 platform (Illumina) using 150 bp pairedend high-output reagents. Raw bcl files were generated using RTA v2.4.11 and were later demultiplexed (using the sample specific index) and converted to fastq format using bcl2fastq v2.17.1.14.

\section{Transcriptome analysis: gene expression analysis}

Demultiplexed raw reads were cleaned using Trimmomatic v0.33 [20] to remove/trim low-quality reads and sequencing adapters as well as using BBMap v34.56 (https://sourceforge.net/projects/bbmap/) to remove reads mapping to the PhiX genome (Illumina spikein). Cleaned fastq reads for each parasite were aligned to the L. salmonis transcriptome (coding sequences) using HiSat2 v2.1.0 [21]. The transcriptome file from ENSEMBL release 44 (ftp.ensemblgenomes.org/pub/ metazoa/release-44/fasta/lepeophtheirus_salmonis) contained the predicted transcriptome from genomic data. It was modified for the aquaporin genes by substituting the predicted cds sequences in the original transcriptome with experimentally determined cds sequences from Stavang et al. [22]. Unmapped reads were filtered out using SAMtools v1.4 [23]. Gene annotation files in GTF format were generated for each parasite and then merged using Cufflinks v2.2.1. [24]. Counts of fragments aligning to each transcript were calculated using FeatureCounts v1.5.2. [25]. Analysis of the differential expression within each group (Ls A-2013 vs Ls V-2013; Ls A-P0 vs Ls V-P0; Ls F2-S vs Ls F2-R) were done using DESeq2 v 1.26.0 [26] (default settings for the count normalization method). The significance level was set to $\alpha=0.05$.

\section{Transcriptome analysis: differentially expressed genes} shared between $\mathrm{H}_{2} \mathrm{O}_{2}$-resistant lice

The DESeq2 analysis generated two lists for each louse group (Ls 2013, Ls P0 and Ls F2), one list of genes upregulated in resistant lice and another list for genes downregulated in resistant lice, both compared to sensitive lice within the same group. Genes that were differentially expressed in the same direction in at least two of the three groups were identified. A Python-script (Additional file 1: Script S1 and Additional file 2: Script S2) was developed to identify the shared genes across all the groups or between two of the groups (Ls 2013 vs Ls P0, Ls 2013 vs Ls F2 and Ls P0 vs Ls F2). Genes were identified by their ENSEMBL name or the GenBank name [22]. The "ENSEMBL Metazoa (transcript)", "protein information" section (http://metazoa.ensembl.org/Lepeophthe irus_salmonis/Info/Index), Uniprot database (https:// www.uniprot.org/) and GenBank protein database (https ://www.ncbi.nlm.nih.gov/genbank/) were used to annotate the genes shared across all the groups.

\section{$\mathrm{H}_{2} \mathrm{O}_{2}$ selection of Ls $V$ lice}

Lice from the $\mathrm{H}_{2} \mathrm{O}_{2}$-resistant strain (Ls V) kept in continuous laboratory culture without exposure to $\mathrm{H}_{2} \mathrm{O}_{2}$ for 4 years (2013-2017) were used as the first generation in an $\mathrm{H}_{2} \mathrm{O}_{2}$ selection experiment comprising 5 generations (F1-F5). Selection was performed on three generations (F1, F2 and F4) with 6 selection events: 3 on-fish and 3 off-fish. Selection on generation 3 (F3) could not be performed due to low lice numbers. The on- and off-fish selections allowed for two exposure events during the louse lifespan.

For the on-fish selection, fish infested with lice (mostly in the pre-adult I stage) were exposed to $1500 \mathrm{ppm}_{2} \mathrm{O}_{2}$ for 15-20 min (recommended concentration and exposure time for bath treatments) in a plastic container at $8.5-11{ }^{\circ} \mathrm{C}$ and under constant aeration. After treatment, fish were transferred to a recovery container with fresh seawater for $1 \mathrm{~h}$, whereupon they were transferred back to their original tanks. Lice found in the treatment and recovery containers were discarded. The lice remaining on the fish were allowed to develop until females had reached the pre-adult II stage and then selected with $\mathrm{H}_{2} \mathrm{O}_{2}$ off-fish. The off-fish method allowed for selection of lice at higher $\mathrm{H}_{2} \mathrm{O}_{2}$ concentrations with good re-attachment to fish of the unaffected lice (90-100\%). Briefly, lice were removed from anesthetized fish and transferred to $1 \mathrm{l}$ glass bottles (25-50 lice per bottle), where they were exposed to 2000 or $2500 \mathrm{ppm}_{2} \mathrm{O}_{2}$ for $30 \mathrm{~min}$. The water was gently mixed every $10 \mathrm{~min}$. Exposures were performed within $4 \mathrm{~h}$ after sampling. Immediately after exposure, the condition of each louse was recorded. The bottles were emptied, and lice attached 
to the bottle walls were considered unaffected. The bottles were re-filled with 11 of fresh seawater with constant aeration and lice were left for $\sim 1 \mathrm{~h}$. Unaffected parasites were then manually put back on the fish (5-10 males and 5-10 females per fish) by laying the lice on a plastic surface with their ventral side upwards, and slightly pressing and rolling one side of the anesthetized fish over all the lice that should infest that fish. Lice developed to adults and produced eggs for the next generation. Affected lice were discarded. Adult females could not be selected with $\mathrm{H}_{2} \mathrm{O}_{2}$ because they were not able to re-attach properly to fish after exposure.

Adult males and females from the F4 generation were removed from anesthetized fish and the egg strings were collected for hatching (F5). Adult F4 females were divided into two groups: one group was immediately fixed in RNAlater, and the other group was exposed to $1000 \mathrm{ppm} \mathrm{H}_{2} \mathrm{O}_{2}$ for $30 \mathrm{~min}\left(\right.$ at $10{ }^{\circ} \mathrm{C}$ ) prior to fixation in RNAlater. The sensitivity to $\mathrm{H}_{2} \mathrm{O}_{2}\left(\mathrm{EC}_{50}\right)$ was determined on the fifth generation (F5). Pre-adult II males and females, and young adult males were used to run a sixdose $\mathrm{H}_{2} \mathrm{O}_{2}$ bioassay in 2019. A six-dose exploratory $\mathrm{H}_{2} \mathrm{O}_{2}$ bioassay was performed before the selection as a reference in 2017. Both bioassay data were modelled using probit modelling in JMP software, and $\mathrm{EC}_{50}$ values with $90 \%$ confidence intervals were calculated separately for males and females. Generalized regression with binominal response distribution was used to test differences between before and after selection of the Ls V strain. Before or after selection and concentration, in addition to their interaction, were used as model effects. The test was run on males and females together as well as separated. Wald Chi-square $\left(\chi^{2}\right)$, degrees of freedom $(d f)$ and the $P$-value are provided. Statistical significance was assumed when $P<0.05$.

\section{qPCR study}

Quantitative polymerase chain reaction (qPCR) was used to validate the RNAseq results for the unexposed adult females (Ls A-2013, Ls V-2013, Ls A-P0 and Ls V-P0) on two genes, catalase and Glp1_v2. An elevated expression of catalase has already been associated with resistance towards hydrogen peroxide in male and female pre-adult stages and in adult males [14], thus this gene was of special interest. The gene Glp1_v2 was chosen since it was significantly downregulated in the three groups of $\mathrm{H}_{2} \mathrm{O}_{2}$-resistant parasites in the RNAseq study (Ls V-2013, Ls V-P0 and Ls F2-R), with a low adjusted $P$-value, $P($ adj $)$, and relatively high $\log 2$ fold change. The two different quantification methods were compared for individual normalized counts (RNAseq) and $\Delta C q$ values (qPCR) for catalase and Glp1_v2. Correlation analysis were performed for each gene with Pearson's correlation coefficient (linear fit) using JMP Pro 15.1.0 (SAS Institute Inc., 2019).

Two other qPCR analysis were performed to investigate the expression of catalase in two different sets of lice. One qPCR was run to test catalase expression in sensitive lice exposed to $\mathrm{H}_{2} \mathrm{O}_{2}$. Five adult females from the original laboratory Ls A strain were exposed to $600 \mathrm{ppm}$ $\mathrm{H}_{2} \mathrm{O}_{2}$ for 30 min. Five unexposed lice were used as controls (calibrator sample). Only unaffected lice from both groups were included in the analysis. The other $\mathrm{qPCR}$ analysis tested the catalase expression on lice from the $\mathrm{H}_{2} \mathrm{O}_{2}$-selected Ls V strain (adult females of the F4 generation). Unexposed parasites $(n=5)$ or parasites exposed to $1000 \mathrm{ppm} \mathrm{H}_{2} \mathrm{O}_{2}$ for $30 \mathrm{~min}(n=5$; all unaffected after the exposure) were used. Ls V-P0 lice were included in the analysis to serve as controls before selection (calibrator sample).

RNA extraction, DNase treatment and RNA cleaning were performed for every sample the same way as samples prepared for RNAseq. First strand cDNA was produced from $1 \mu \mathrm{g}$ of cleaned RNA using the qScript ${ }^{\mathrm{TM}}$ cDNA synthesis (reverse transcriptase) kit (Quanta Biosciences, MD, USA). The cDNA was cleaned with the DNA Clean \& Concentrator ${ }^{\mathrm{TM}}-5$ kit (Zymo Research) and diluted 1:10 before being used as a PCR template for the qPCR using gene-specific primers and SsoAdvanced Universal SYBR Green Supermix (Bio-Rad, CA, USA), following the manufacturer's protocol. Each qPCR reaction was optimized for $11 \mu \mathrm{l}$ total reaction volume, $150 / 150$ or $300 / 300 \mathrm{nM}$ primer concentration and $2 \mu \mathrm{l}$ of template, corresponding to $0.2 \mu \mathrm{g}$ cDNA/RNA. Reactions were run in duplicate or triplicate and two negative controls were added, a non-template control and a no-reverse transcriptase control. The range of efficiencies for qPCR reactions were $96-98 \%$ for reference and target gene specific primers. The qPCR was run on a Bio-Rad CFX96 realtime system (Bio-Rad) under the following conditions: $95{ }^{\circ} \mathrm{C}$ for $30 \mathrm{~s}$ followed by 40 cycles of amplification at $95^{\circ} \mathrm{C}$ for $10 \mathrm{~s}$ and $60^{\circ} \mathrm{C}$ for $50 \mathrm{~s}$. After qPCR, the homogeneity and specificity of the PCR products was confirmed by melting curve analysis, agarose gel electrophoresis and Sanger sequencing. Relative gene expression was determined by the $\Delta \mathrm{Cq}$ method $\left(\Delta \mathrm{Cq}=\mathrm{Cq}_{\text {target }}-\mathrm{Cq}_{\text {reference }}\right)$, where $\mathrm{Cq}_{\text {target }}$ is the $\mathrm{Cq}$ values for catalase or Glp1_v2, and $\mathrm{Cq}_{\text {reference }}$ the average of the elongation factor 1-alpha and prohibitin-2 genes (see Table 2 for primer details). The use of two reference genes with different expression levels (high for elongation factor 1-alpha and low for prohibitin-2, in adult female lice) is beneficial for the qPCR accuracy when the expression of the target genes in the different samples is expected to have a relatively big range. The expression of both reference genes was stable under $\mathrm{H}_{2} \mathrm{O}_{2}$ exposure in adult $L$. salmonis females. 
Table 2 Primers used in the qPCR study

\begin{tabular}{|c|c|c|c|c|}
\hline Gene & Primer name & Primer sequence & Primer concentration (nM) & Product size (bp) \\
\hline \multirow[t]{2}{*}{ Catalase } & Ls_Cat_6 F & CCACAGAACAACTTGCCAAC & $150 / 150$ & 157 \\
\hline & Ls_Cat_6R & GCCATTTCGTCCATAAATGC & & \\
\hline \multirow[t]{2}{*}{ Glp1_v2 } & Ls_Glp1_2F & TCGGCTCCAGGAATTGTTCT & $300 / 300$ & 200 \\
\hline & Ls_Glp1_2R & GGTCCTAAATCTCTCGCTGGG & & \\
\hline \multirow[t]{2}{*}{ Elongation factor 1-alpha } & Ls_gEF_2F & ATGGCACGGAGACAACATGT & $150 / 150$ & 206 \\
\hline & Ls_gEF_2R & CGGGCACTGTTCCAATACCT & & \\
\hline \multirow[t]{2}{*}{ Prohibitin-2 } & Ls_gProhib2_2F & GCTCATCACACAGCGTCAAC & $300 / 300$ & 176 \\
\hline & Ls_gProhib2_2R & CAGCTCTTTGGGCCTCTTGT & & \\
\hline
\end{tabular}

Fold change in gene expression was calculated according to the $2^{-(\Delta \Delta C \mathrm{q})}$ method, using the Cq values of the corresponding control groups as calibrator sample.

\section{Results and discussion}

Crossing experiment and bioassays

In order to obtain both $\mathrm{H}_{2} \mathrm{O}_{2}$-sensitive and $\mathrm{H}_{2} \mathrm{O}_{2}$-resistant lice for the RNAseq study, F2 adult females were selected with two-dose $\mathrm{H}_{2} \mathrm{O}_{2}$ bioassays. $\mathrm{F} 2$ lice belonged to 2 different families, originating from batch crossing of sensitive (Ls A) and resistant (Ls V) lice. Table 3 shows the number of F2 adult females affected at the different $\mathrm{H}_{2} \mathrm{O}_{2}$ doses for each family group. There were no significant differences between the family groups $\left(\chi^{2}=0.023, d f=1, P=0.88\right)$, indicating that inheritance of resistance was not sex-specific (i.e. there were similar numbers of affected lice independently of which strain the P0 males and females belonged to).

\section{RNAseq expression analysis}

RNAseq gene expression analysis (DESeq2) showed that the groups Ls V-2013 and Ls F2-R each had more than 2000 genes differentially regulated compared to the corresponding sensitive groups, Ls A-2013 and Ls F2-S (Fig. 1, Additional file 3: Dataset S1). The Ls V-P0 lice had less than 150 genes differentially regulated compared to Ls A-P0.

The number of differentially expressed genes in the original resistant and sensitive strains collected in 2013 (see Table 1 for strain details), likely reflect both genes associated with resistance and genes necessary for adaptation to different environments. In the P0 generation, environmental conditions had been similar between the strains for two years and without any exposure to medicinal compounds, thus some differences related to environmental adaptation were likely evened out. The subsequent increase of differentially expressed genes from $\mathrm{P} 0$ generations to the $\mathrm{H}_{2} \mathrm{O}_{2}$-selected F2-generation
Table 3 Number of F2 adult female lice affected in two-dose $\mathrm{H}_{2} \mathrm{O}_{2}$ bioassays

\begin{tabular}{llll}
\hline & \multicolumn{2}{l}{ Crossing and bioassays } & \\
\cline { 2 - 4 } & Family group 1 & Family group 1 & Family group 2 \\
\hline 0 ppm (Control) & $1 / 18(6 \%)$ & $0 / 5(0 \%)$ & $1 / 18(6 \%)$ \\
600 ppm & $2 / 16(13 \%)$ & $1 / 18(6 \%)$ & $8 / 32(25 \%)$ \\
1800 ppm & $13 / 15(87 \%)$ & $12 / 18(67 \%)$ & $16 / 25(64 \%)$ \\
\hline
\end{tabular}

Notes: Bioassays: 30 min exposure; three bioassays in total (two using lice from family group 1 and one with lice from family group 2). Results indicated as fractions (number of affected lice out of total lice per dose) and percentages (in parentheses). Family group 1, females from the sensitive Ls A strain were crossed with males from the $\mathrm{H}_{2} \mathrm{O}_{2}$-resistant $\mathrm{Ls} V$ strain in the $\mathrm{PO}$ generation; family group 2 , males from the sensitive $L s A$ strain were crossed with females from the $L s V$ strain

could suggest induction of a high number of genes due to the $\mathrm{H}_{2} \mathrm{O}_{2}$ exposure. The $\mathrm{F} 2$ parasites were sampled immediately after a 30 min $\mathrm{H}_{2} \mathrm{O}_{2}$ exposure, thus differential regulation of the expression of a number of genes as a consequence of this exposure within this short time frame could be questioned. It has though been demonstrated that induction of genes needed to cope with oxidative stress can happen within two hours [27], possibly also sooner, although this has not been studied. Several putative methyltransferases and transcription factors (typically involved in gene transcription activation or repression) were found differentially expressed in our RNAseq study (data not shown), supporting the induction theory.

\section{Catalase expression}

The catalase gene was previously found differentially expressed in $\mathrm{H}_{2} \mathrm{O}_{2}$-sensitive and -resistant lice [14] and its expression level has been introduced as a $\mathrm{H}_{2} \mathrm{O}_{2}$ resistance marker in the salmon industry [15]. The present RNAseq study sought to validate the use of catalase expression as a resistance marker in adult females, as this developmental stage was not included in a previous study 
No. of genes upregulated in resistant lice

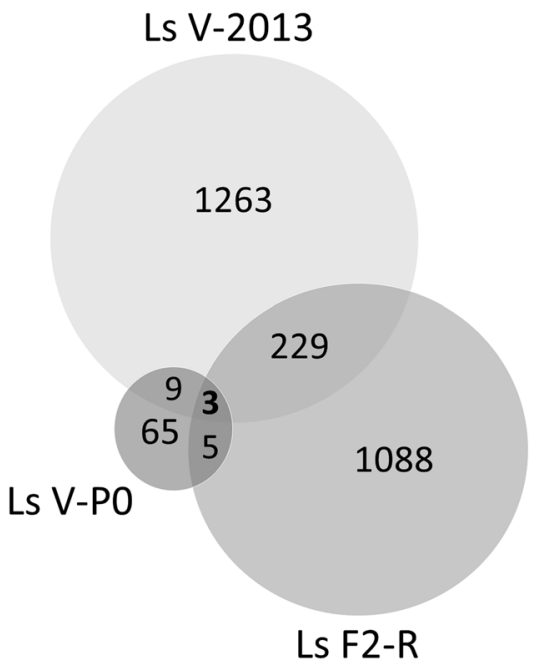

No. of genes downregulated in resistant lice

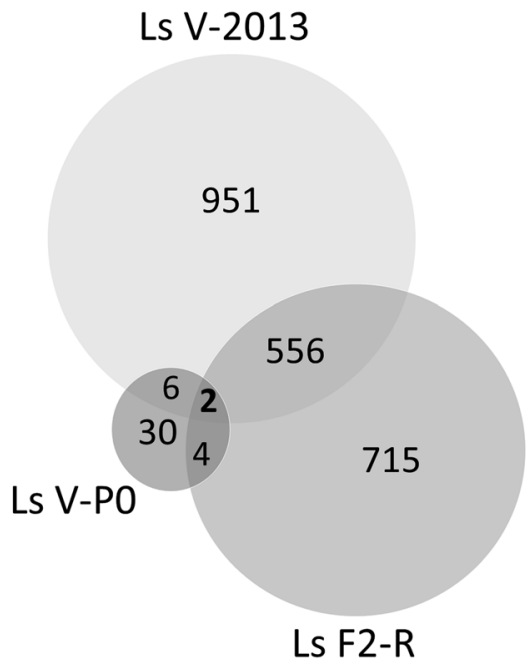

Fig. 1 Number of genes differentially expressed in the $\mathrm{H}_{2} \mathrm{O}_{2}$-resistant lice groups ( $\mathrm{LS} \mathrm{V-2013,} \mathrm{Ls} \mathrm{V-P0} \mathrm{and} \mathrm{Ls} \mathrm{F2-R)} \mathrm{versus} \mathrm{the} \mathrm{corresponding} \mathrm{sensitive}$ groups (Ls A-2013, LS A-P0 and Ls F2-S), separately for up- and downregulated genes. Numbers in the circles but outside the intersections represent the genes differentially expressed in only one group. Numbers in the intersection of the circles represent the differentially expressed genes shared between two or three groups

[14]. There were significantly higher numbers of catalase transcripts in resistant lice exposed to $\mathrm{H}_{2} \mathrm{O}_{2}$ (Ls V-2013 and Ls F2-R) than in sensitive lice (Table 4, Fig. 2). However, the number of catalase transcripts in the P0 generation of Ls V, a $\mathrm{H}_{2} \mathrm{O}_{2}$-resistant strain that was unexposed to $\mathrm{H}_{2} \mathrm{O}_{2}$ for several generations, did not differ significantly from the sensitive Ls A-P0. The qPCR validation confirmed the gene expression pattern found for 2013 and P0 RNAseq samples: Ls V-2013 had higher catalase expression than Ls A, while the expression in Ls V-P0 and Ls A was similar (Figs. 2, 3 and 4).

Two six-dose $\mathrm{H}_{2} \mathrm{O}_{2}$ bioassays were run after completion of the RNAseq study to check the sensitivity of the unexposed Ls $\mathrm{V}$ strain. The $\mathrm{EC}_{50}$ value for pre-adult II females from the Ls V laboratory strain was 1635 ppm, eight times higher than the Ls A strain (216 ppm) (Table 5; 2017 bioassay for Ls V), and the value for Ls $\mathrm{V}$ adult females was 1063 ppm (90\% CI: 664-1703; $n=34$ ), suggesting that Ls V-P0 lice were still resistant to $\mathrm{H}_{2} \mathrm{O}_{2}$ when enrolled in the RNAseq study. Based on the results from the two-dose $\mathrm{H}_{2} \mathrm{O}_{2}$ bioassays performed on F2 lice, the Ls V-P0 descendants, the $\mathrm{EC}_{50}$ value for F2 lice would be expected between 600 and $1800 \mathrm{ppm}$ (Table 3), almost three times higher than the value for Ls A lice. DESeq2 analysis for Ls F2-R showed that these lice had on average close to three times higher numbers of catalase transcripts than their grandparents, Ls V-P0 (Table 4). In addition, catalase was one of the most important differentially expressed genes in Ls F2-R lice, having the lowest $P(\operatorname{adj})$ value and without overlap in the range of normalized counts between F2 sensitive and resistant lice, efficiently separating those groups. These results indicate that catalase expression is induced by $\mathrm{H}_{2} \mathrm{O}_{2}$ exposure in resistant lice. The induction of catalase expression after $\mathrm{H}_{2} \mathrm{O}_{2}$ exposure has previously been demonstrated in a penaeid shrimp. The gene was significantly upregulated $2 \mathrm{~h}$ after injecting $0.1 \% \mathrm{H}_{2} \mathrm{O}_{2}$ in the shrimp body [27].

In contrast to resistant lice, sensitive lice do not appear to induce catalase expression following $\mathrm{H}_{2} \mathrm{O}_{2}$ exposure. This was shown with qPCR on adult females from the sensitive Ls A strain unaffected after $30 \mathrm{~min}$ exposure to $600 \mathrm{ppm} \mathrm{H}_{2} \mathrm{O}_{2}$, when compared to a parallel group of unexposed Ls A females (Fig. 5). However, the inter-individual variation in the exposed group, was smaller than in the unexposed one. A similar trend is observed among sensitive lice enrolled in the RNAseq study: Ls A-2013 and Ls A-P0 (unexposed) vs F2-S (exposed) (Table 4, Fig. 2).

$\mathrm{H}_{2} \mathrm{O}_{2}$ resistance has been demonstrated to be hereditary $[11,14]$. The heritable factor may thus be the ability to quickly induce catalase expression. The induction of catalase expression poses a challenge for its use as an $\mathrm{H}_{2} \mathrm{O}_{2}$ resistance marker, since unexposed resistant lice may have low catalase expression and could erroneously be classified as sensitive. On the other hand, after a short 
Table 4 Gene expression data of several genes differentially expressed in the louse groups Ls 2013, P0 and F2

\begin{tabular}{|c|c|c|c|c|c|}
\hline \multirow[t]{2}{*}{ Gene } & \multirow[t]{2}{*}{ Lice group } & \multicolumn{2}{|c|}{ Normalized counts: arithmetic mean \pm SD (range) } & \multirow[t]{2}{*}{$\log 2 \mathrm{FC}$} & \multirow[t]{2}{*}{$P(\mathrm{adj})$} \\
\hline & & LS A/F2-S & LsV/F2-R & & \\
\hline \multirow[t]{3}{*}{ Catalase } & 2013 & $819 \pm 169(675-1055)$ & $3429 \pm 1662(2236-6165)$ & 2.07 & $<0.001$ \\
\hline & PO & $954 \pm 330(696-1326)$ & $706 \pm 195(491-963)$ & -0.43 & 0.784 \\
\hline & $\mathrm{F} 2$ & $1161 \pm 164(891-1386)$ & $2072 \pm 366(1580-2821)$ & 0.84 & $<0.001$ \\
\hline \multirow[t]{3}{*}{ DNA-polymerase } & 2013 & $374 \pm 50(331-447)$ & $464 \pm 49(390-505)$ & 0.32 & 0.044 \\
\hline & PO & $585 \pm 83(495-658)$ & $930 \pm 142(812-1134)$ & 0.67 & 0.024 \\
\hline & F2 & $217 \pm 73(144-344)$ & $320 \pm 125(165-548)$ & 0.56 & 0.045 \\
\hline \multirow[t]{3}{*}{ Nesprin-like } & 2013 & $3865 \pm 345(3522-4290)$ & $5297 \pm 538(4644-6116)$ & 0.46 & $<0.001$ \\
\hline & PO & $5066 \pm 234(4837-5304)$ & $7036 \pm 825(5803-7547)$ & 0.47 & 0.034 \\
\hline & $\mathrm{F} 2$ & $3271 \pm 527(2887-4498)$ & $4021 \pm 409(3158-4403)$ & 0.30 & 0.005 \\
\hline \multirow[t]{3}{*}{ NA } & 2013 & $14 \pm 4(8-17)$ & $33 \pm 15(19-52)$ & 1.19 & 0.018 \\
\hline & PO & $21 \pm 17(11-41)$ & $95 \pm 49(57-164)$ & 2.16 & 0.026 \\
\hline & $\mathrm{F} 2$ & $10 \pm 5(4-20)$ & $21 \pm 10(5-38)$ & 1.03 & 0.015 \\
\hline \multirow[t]{3}{*}{ ERP29 } & 2013 & $90 \pm 13(77-102)$ & $56 \pm 15(40-74)$ & -0.69 & 0.015 \\
\hline & PO & $114 \pm 16(96-128)$ & $50 \pm 4(45-55)$ & -1.20 & $<0.001$ \\
\hline & F2 & $110 \pm 21(76-140)$ & $81 \pm 20(44-118)$ & -0.44 & 0.019 \\
\hline \multirow[t]{3}{*}{ Glp1_v2 } & 2013 & $112 \pm 39(74-164)$ & $15 \pm 6(10-26)$ & -2.89 & $<0.001$ \\
\hline & PO & $77 \pm 11(64-86)$ & $40 \pm 5(35-44)$ & -0.93 & 0.025 \\
\hline & $\mathrm{F} 2$ & $197 \pm 83(39-292)$ & $88 \pm 45(40-181)$ & -1.16 & 0.002 \\
\hline \multirow[t]{3}{*}{ Aqp12L1 } & 2013 & $158 \pm 14(140-173)$ & $99 \pm 32(73-152)$ & -0.68 & 0.013 \\
\hline & PO & $162 \pm 26(144-192)$ & $148 \pm 23(130-181)$ & -0.13 & 0.957 \\
\hline & F2 & $182 \pm 29(130-219)$ & $141 \pm 25(104-185)$ & -0.37 & 0.010 \\
\hline \multirow[t]{3}{*}{ Aqp 12L2 } & 2013 & $56 \pm 14(42-75)$ & $15 \pm 3(13-20)$ & -1.91 & $<0.001$ \\
\hline & PO & $29 \pm 18(11-46)$ & $24 \pm 5(19-30)$ & -0.29 & 0.960 \\
\hline & F2 & $98 \pm 18(69-124)$ & $66 \pm 21(31-103)$ & -0.57 & 0.012 \\
\hline \multirow[t]{3}{*}{ Glp2 } & 2013 & $21 \pm 7(15-31)$ & $5 \pm 6(0-14)$ & -1.98 & 0.045 \\
\hline & PO & $17 \pm 10(7-26)$ & $20 \pm 7(16-30)$ & 0.22 & 0.976 \\
\hline & F2 & $25 \pm 12(6-42)$ & $11 \pm 5(1-17)$ & -1.12 & 0.008 \\
\hline \multirow[t]{3}{*}{ Glp3_v1 } & 2013 & $149 \pm 30(110-182)$ & $297 \pm 74(183-365)$ & 0.99 & $<0.001$ \\
\hline & PO & $222 \pm 34(185-253)$ & $174 \pm 56(120-253)$ & -0.35 & 0.855 \\
\hline & $\mathrm{F} 2$ & $134 \pm 34(91-203)$ & $121 \pm 18(82-148)$ & -0.16 & 0.378 \\
\hline
\end{tabular}

Number of lice included in each group $(n)$ is provided in Table 1

Notes: Upregulation is indicated as log2FC positive values; downregulation as log2FC negative values. Statistical significance is indicated in bold ( $P$ (adj) values). ENSEMBL L. salmonis transcriptome was used in the analysis, but the sequences of genes coding for aquaporins were replaced by GenBank entries: Catalase, EMLSAT00000007315; DNA-polymerase, EMLSAT00000002584; Nesprin-like, EMLSAT00000005972; NA (unannotated), EMLSAT00000005947; ERP29, EMLSAT00000009549; Glp1_v2, KR005661.1; Aqp12L1, KR005665.1; Aqp12L2, KR005666.1; Glp2, KR005662.1; Glp3_v1, KR005663.1

Abbreviations: Ls A/F2-S, sensitive lice; Ls V/F2-R, resistant lice; SD, standard deviation; Log2FC, log2 fold change; $P$ (adj), $P$-value for normalized counts ( $a=0.05$ )

exposure to $\mathrm{H}_{2} \mathrm{O}_{2}$, sensitive and resistant lice seem to be easily separable by catalase expression.

\section{New candidate genes}

To identify more genes associated with $\mathrm{H}_{2} \mathrm{O}_{2}$ resistance, differentially expressed genes from the Ls 2013, Ls P0 and Ls F2 generations were compared. The resistant lice that had been exposed to $\mathrm{H}_{2} \mathrm{O}_{2}$ (Ls V-2013 and Ls F2-R) shared 790 differentially expressed genes (Fig. 1). This supports the hypothesis that $\mathrm{H}_{2} \mathrm{O}_{2}$ exposure can induce the expression of several genes, even within a time-span of $30 \mathrm{~min}$. The complete list of genes shared across two or all three groups is presented in Additional file 4: Dataset S2.

Only five genes (three upregulated and two downregulated in resistant lice) were differentially expressed in all three groups (Ls V-2013, Ls V-P0 and Ls F2-R) (Figs. 1, 2), thus irrespective of $\mathrm{H}_{2} \mathrm{O}_{2}$ exposure. Table 4 shows the gene expression and annotation data for those genes. The fold change ranged from c.1.2 to 8, up- or downregulated depending on the gene. The three genes consistently upregulated in resistant lice encoded a DNA 
(See figure on next page.)

Fig. 2 Gene expression data (normalized counts from the RNAseq study) of catalase and five genes significantly differentially expressed across 2013, P0 and F2 groups (DNA-polymerase, Nesprin-like, NA, ERP29 and Glp1_v2). Ls A-2013 (white circles), Ls V-2013 (grey circles), LS A-P0 (white triangles), Ls V-P0 (grey triangles), Ls F2-S (white diamonds), Ls F2-R (grey diamonds). Ls A/F2-S represent the sensitive lice, and Ls V/F2-R, the resistant ones. Solid lines represent the arithmetic mean in each group. Dark grey and black diamonds in the Ls F2-R group correspond to the same individual lice in both catalase and Glp1_v2 graphs

polymerase (delta subunit 3), a Nesprin-like protein and an unannotated small protein (named NA; 77 aa long). DNA polymerase is an enzyme that synthesize DNA from deoxyribonucleotides, and the delta subunit 3 plays a role in high fidelity genome replication. The protein identified as Nesprin-like contained a KASH domain and a spectrin repeat (spectrin/alpha-actinin). It probably belongs to the Nesprin-1 or -2 type, actin-binding proteins involved in the maintenance of nuclear organization and structural integrity. The NA protein might be a mini-protein with regulatory functions. A large amount of mini- and micro-proteins (small proteins usually $<100$ aa long) acting as negative or positive regulators, have been identified in unicellular organisms, plants and animals [28, 29]. For example, some small proteins sequester their targets into non-functional complexes, others attract chromatin repressor proteins, or others interact with ion channels compromising their transport capacity.

The two genes downregulated in all resistant lice were the genes encoding endoplasmic reticulum resident protein 29 (ERP29) and an aquaporin protein (Glp1_v2). ERP29 plays an important role in the processing of secretory proteins within the endoplasmic reticulum. Aquaporins are protein channels that facilitate the rapid transport of water and other small solutes such as $\mathrm{H}_{2} \mathrm{O}_{2}$ and gasses [22, 30-34].

The most interesting, differentially expressed gene was Glp1_v2, one of the aquaglyceroporins (Glp) identified by Stavang et al. [22] in L. salmonis. Stavang et al. [22] identified a total of seven aquaporins, with several splice variants, in the salmon louse: two classical aquaporins, Bib and PripL (Prip-like); three aquaglyceroporins, Glp1_v1, Glp1_v2, Glp2, Glp3_v1 and Glp3_v2 (v1 and v2 represent the splice variants); and two unorthodox aquaporins, Aqp12L1 (Aqp12-like1) and Aqp12L2 (Aqp12-like 2). All but Glp1_v1 and Glp3_v2 were detected in our RNAseq data. Stavang et al. [22] reported Glp1_v1 only in preadult II and adult males, while Glp1_v2 was detected in both sexes. Glp3_v2 was expressed mostly in nauplius II stage. Table 4 shows the gene expression data for several aquaporins in our study. There were no statistically significant differences in the expression of Bib or PripL within any of the Ls 2013, Ls P0 or Ls F2 groups (data not shown). However, Glp1_v2 was statistically significantly downregulated in all $\mathrm{H}_{2} \mathrm{O}_{2}$-resistant groups (Ls V-2013,
Ls V-P0 and Ls F2-R). The qPCR analysis revealed a similar gene expression pattern, with Ls V-2013 and Ls V-P0 having lower Glp1_v2 expression levels compared to the corresponding Ls A groups (Figs. 2, 3 and 4). Glp 2 was significantly downregulated in two groups, Ls V-2013 and Ls F2-R, but the expression of this gene was low. Glp3_v1 was upregulated in only Ls V-2013. The unorthodox aquaporins, Aqp12L1 and Aqp12L2, were statistically significantly downregulated in Ls V-2013 and Ls F2-R groups, but not in the Ls V-P0 lice.

It has been demonstrated that certain aquaglyceroporins and unorthodox aquaporins are able to transport $\mathrm{H}_{2} \mathrm{O}_{2}$ through cell membranes in several organisms [32, 33]. Glps have an open pore configuration in L. salmonis [22], allowing bigger molecules than water, like urea and glycerol, to pass through the channel. Miller et al. [32], found that one aquaglyceroporin (AQP3) and one unorthodox aquaporin (AQP8) transported $\mathrm{H}_{2} \mathrm{O}_{2}$ through mammalian cell membranes. However, the classical aquaporin AQP1, did not transport $\mathrm{H}_{2} \mathrm{O}_{2}$. As Glp1_v2 was downregulated in all three groups of $\mathrm{H}_{2} \mathrm{O}_{2}$-resistant lice in the current study, a possible involvement in the influx or distribution of $\mathrm{H}_{2} \mathrm{O}_{2}$ in the salmon louse body or cells seems probable; the lower the number of Glp1_v2 channels, the lesser amount of exogenous $\mathrm{H}_{2} \mathrm{O}_{2}$ can enter and cause toxic effects. The downregulation of Aqp12L1 and Aqp12L2 in resistant lice exposed to $\mathrm{H}_{2} \mathrm{O}_{2}$ may also indicate a role of these proteins as $\mathrm{H}_{2} \mathrm{O}_{2}$ channels. This goes especially for Aqp12L2, with almost 4-fold downregulation and very low $P(\mathrm{adj})$ value $(<0.001)$ in the $L s$ 2013 groups (Table 4). As in the case of Glps, Stavang et al. [22] also found an open pore configuration in the 3D modelling of Aqp12L2.

Several authors have reported the role of aquaporins as drug transporters in other parasites, as well as a link between aquaporins and drug resistance [35]. Faghiri \& Skelly [36], showed the presence of a putative aquaglyceroporin $(\mathrm{SmAQP})$ in the tegument of the parasitic worm Schistosoma mansoni. It was proven that SmAQP can transport water and an anti-parasitic compound (potassium antimonyl tartrate) across the parasite tegument. In addition, parasites with reduced levels of SmAQP exhibited a greater resistance to the anti-parasitic agent. In trypanosomatid parasites, such as Leishmania spp. and Trypanosoma spp., certain aquaporins transport trivalent 

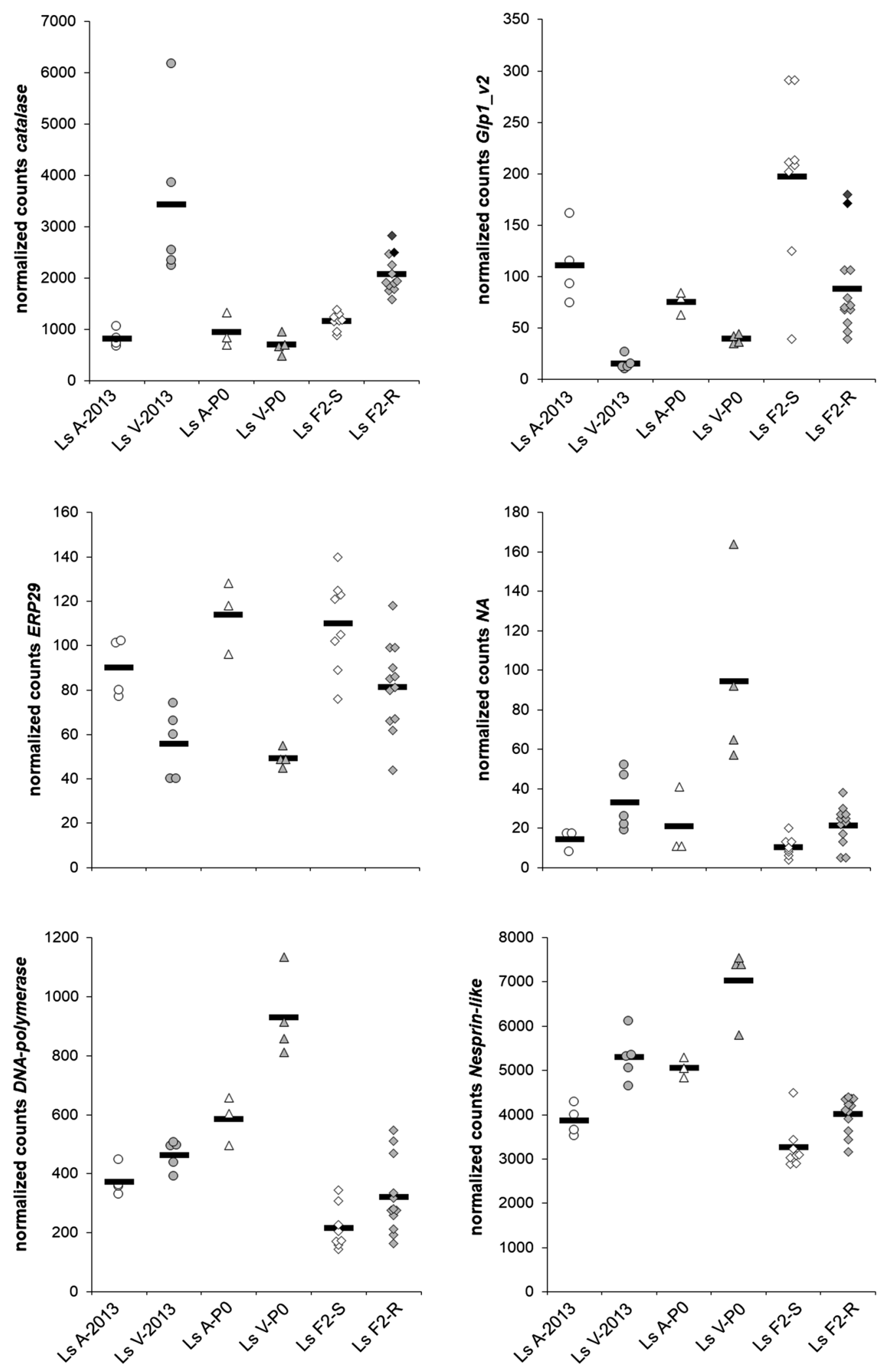

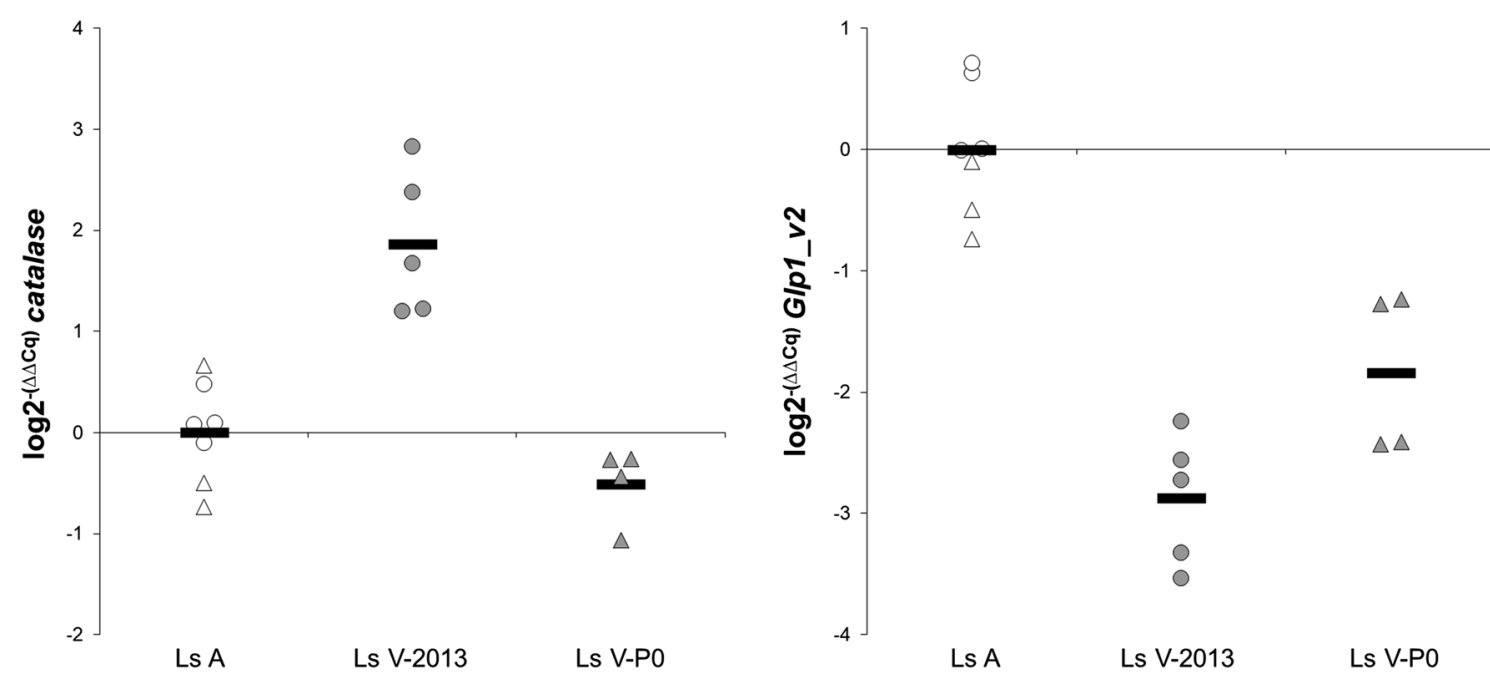

Fig. 3 qPCR validation study for catalase and Glp1_V2 genes in the louse groups Ls A-2013 (white circles), Ls V-2013 (grey circles), Ls A-P0 (white triangles) and Ls V-PO (grey triangles). Ls A represent the sensitive lice, and LS V, the resistant lice. Solid lines represent the arithmetic mean in each group. Data shown as fold change $\left(\log 2^{-(\Delta \Delta C q)}\right)$ referred to Ls A (Ls A-2013 and Ls A-P0) (calibrator sample). Statistical analysis was not performed due to the low sample size in some of the groups
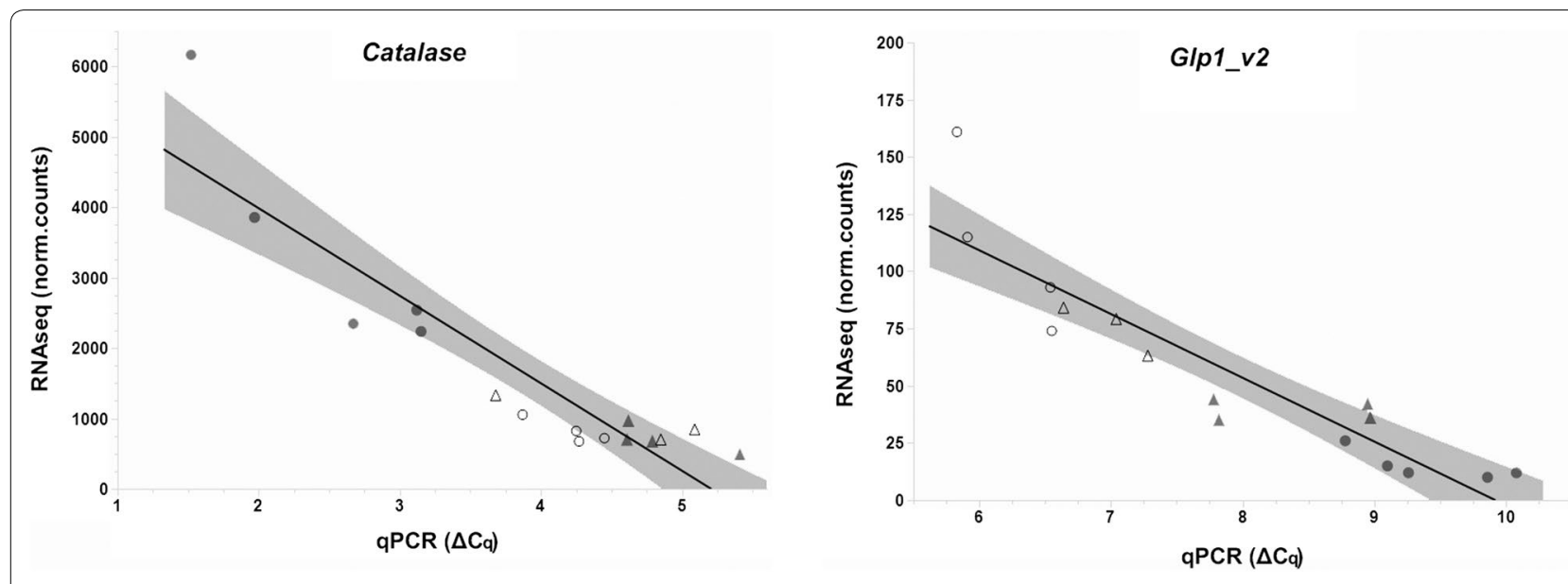

Fig. 4 Correlation between RNAseq (normalized counts) and qPCR ( $\triangle$ Cq values) for the expression of catalase and Glp1_V2 in sensitive (Ls A-2013 and Ls A-PO; white circles and triangles, respectively) and resistant lice (Ls V-2013 and Ls V-PO; grey circles and triangles, respectively). A linear fit with the $95 \%$ confidence interval (shaded area) has been added. Pearson's correlation coefficient $(r)$ was calculated to test the strength of the linear fit (statistically significant if $P<0.05$ )

metalloids (SbIII and AsIII) through the parasite membranes [37]. The aquaglyceroporin LmAQP1 transports SbIII in Leishmania spp. [38]. Drug-resistant parasites showed downregulation of the LmAQP1 gene [39], and RNA levels correlated with drug concentration. Resistance to melarsoprol and pentamidine is common among African trypanosomes [40]. The authors found that the loss of function of an aquaglyceroporin, AQP2, was linked to drug resistance.
Studies have shown that the amount of functional proteins can be related to the amount of RNA transcripts, but also to the activation state or degradation rate of the proteins. For example, a mitogen-activated protein kinase 2 (MPK2) stabilizes LmAQP1 protein by phosphorylation in Leishmania major [41], and dephosphorylation made LmAQP1 more susceptible to degradation. Altered AQP1 and MPK2 (by site-directed mutagenesis) reduced the drug uptake and drug sensitivity. Catalase activity 
Table 5 Bioassay data for pre-adult II (males and females) and young adult males exposed to $\mathrm{H}_{2} \mathrm{O}_{2}$ for 30 min

\begin{tabular}{|c|c|c|}
\hline Louse strain & $\mathrm{H}_{2} \mathrm{O}_{2}$ exposure data & $\mathrm{EC}_{50}(\mathrm{ppm})(90 \% \mathrm{Cl})$ \\
\hline Ls A laboratory strain (Ref) & $\begin{array}{l}2013 ; 10-12^{\circ} \mathrm{C} ; \\
N \text { and dose }\end{array}$ & $216(153-305)$ \\
\hline Ls V F0 (Ref) ${ }^{\mathrm{a}}$ & $\begin{array}{l}2013 ; 10-12^{\circ} \mathrm{C} ; \\
N \text { and dose }\end{array}$ & $2127(1253-3610)$ \\
\hline Ls VF1 (Ref) ${ }^{a}$ & $\begin{array}{l}2013 ; 10-12{ }^{\circ} \mathrm{C} ; \\
N \text { and dose }\end{array}$ & 1767 (1494-2090) \\
\hline Ls V laboratory strain before $\mathrm{H}_{2} \mathrm{O}_{2}$ selection & $\begin{array}{l}2017 ; 10-11^{\circ} \mathrm{C} ; \\
\mathrm{N}: 25 \text { females and } 22 \text { males; } \\
0,600,1400,2200,3000,4200 \mathrm{ppm}\end{array}$ & $\begin{array}{l}\text { Females: } 1635 \text { (734-3643); } \\
\text { Males: } 1795 \text { (1095-2943) }\end{array}$ \\
\hline Ls V laboratory strain (F5) after $\mathrm{H}_{2} \mathrm{O}_{2}$ selection & $\begin{array}{l}2019 ; 10^{\circ} \mathrm{C} ; \\
\text { N: } 130 \text { females and } 118 \text { males; } \\
0,600,1400,2200,3000,4200 \text { ppm }\end{array}$ & $\begin{array}{l}\text { Females: } 2441 \text { (2012-2961); } \\
\text { Males: } 1861 \text { (1482-2337) }\end{array}$ \\
\hline
\end{tabular}

Notes: $\mathrm{H}_{2} \mathrm{O}_{2}$ exposure data: year; water temperature; $N$, total number of lice used (all chemical concentrations together); doses (ppm $=$ mg $\mathrm{I}^{-1}$ )

a Ref: Previously published data for Ls V (resistant strain) and Ls A (sensitive strain) in Helgesen et al. 2015 [11]. EC 50 values for males and females together; $95 \%$ CI. General nominal concentration ranging from 0 to $5000 \mathrm{ppm}$, adjusted for each strain. $\mathrm{N}$ not available

Abbreviations: $\mathrm{EC}_{50}$, concentration affecting $50 \%$ of the lice; $\mathrm{Cl}$, confidence interval; Ls A, sensitive strain; Ls V, $\mathrm{H}_{2} \mathrm{O}_{2}$-resistant strain

can also be regulated by reversible phosphorylation via kinase enzymes by increasing the affinity of the enzyme for $\mathrm{H}_{2} \mathrm{O}_{2}$ [42]. In our L. salmonis RNAseq study, we found

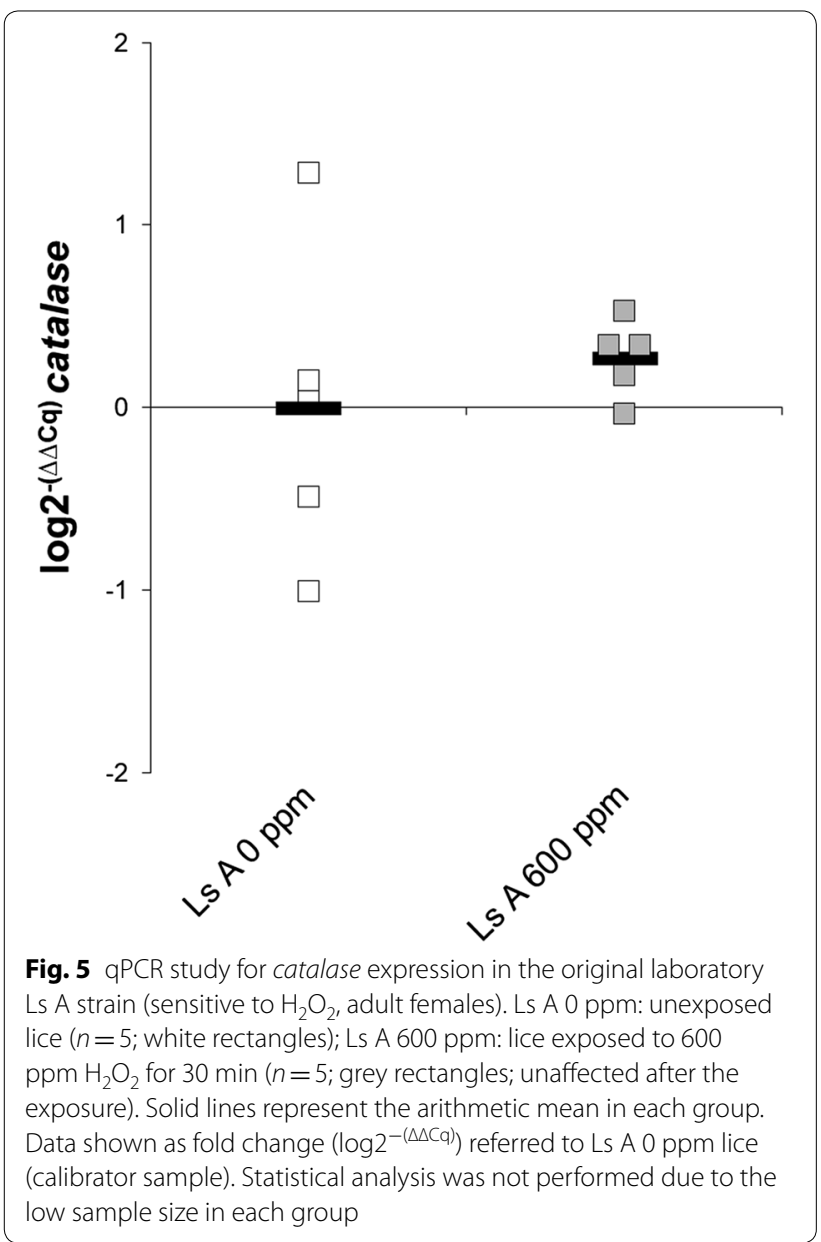

four putative mitogen-activated protein kinases differentially expressed in $\mathrm{H}_{2} \mathrm{O}_{2}$-sensitive and $\mathrm{H}_{2} \mathrm{O}_{2}$-resistant lice (data not shown), indicating that drug sensitivity might be linked to regulation of gene expression, but also to the amount and functionality of the proteins.

The role of DNA-polymerase, Nesprin-like, NA and ERP29 in $\mathrm{H}_{2} \mathrm{O}_{2}$ resistance is difficult to establish. Nevertheless, these genes, together with Glp1_v2, may become very interesting candidate genes for developing molecular markers for monitoring $\mathrm{H}_{2} \mathrm{O}_{2}$ resistance, since they are consistently up- or downregulated in all resistant louse groups.

Only one $\mathrm{H}_{2} \mathrm{O}_{2}$-resistant strain (Ls V) could be included in the present study, which make generalizations about the $\mathrm{H}_{2} \mathrm{O}_{2}$ resistance mechanisms and markers challenging. However, F2 resistant lice might be considered a different lice population/strain since it was a mix of a sensitive (Ls A) and a resistant strain (Ls V). F2 lice had a wide range of $\mathrm{H}_{2} \mathrm{O}_{2}$ sensitivities, with some individuals affected at $600 \mathrm{ppm} \mathrm{H}_{2} \mathrm{O}_{2}$ and some unaffected at $1800 \mathrm{ppm}$. At the molecular level, there were statistically significant differences between sensitive and resistant F2 lice in normalized counts for DNA-polymerase, Nesprin-like, NA, ERP29 and Glp1_ $v 2$, but there were overlaps in the group ranges for all of these genes (Table 4). This overlap may suggest that $\mathrm{H}_{2} \mathrm{O}_{2}$ resistance in F2 lice came from several up- and downregulated genes combined in slightly different ways, enabling individual parasites to survive $1800 \mathrm{ppm}$ $\mathrm{H}_{2} \mathrm{O}_{2}$. As an example, the two F2 resistant lice with high number of Glp1_v2 reads (Fig. 2, dark grey and black diamonds), are the ones with higher catalase expression, possibly suggesting a compensatory effect: high numbers of Glp1_v2 could mean that more exogenous 
$\mathrm{H}_{2} \mathrm{O}_{2}$ would enter the louse body and cells. The louse would then need more catalase for breaking down the $\mathrm{H}_{2} \mathrm{O}_{2}$ and survive the exposure. This observation on the expression overlap of several genes, suggests that the $\mathrm{H}_{2} \mathrm{O}_{2}$-resistance mechanisms can vary slightly between individuals. However, the general resistance pattern is the same, at least in related louse strains. According to these observations, we propose the development of a set of molecular markers based on the expression of catalase, Glp1_v2, DNA-polymerase, Nesprin-like, NA and ERP29 genes, that should be validated on other louse populations/strains.

The use of gene expression as molecular marker for reduced sensitivity towards a treatment is challenging, since the expression may also be affected by other factors. For example, different dosages, exposure times, temperature, handling stress, developmental stage and sex may all influence gene expression, regardless of treatment tolerance. A standardized protocol for lice collection, handling, fixation and $\mathrm{H}_{2} \mathrm{O}_{2}$ exposure (if necessary), is thus warranted for an efficient performance of gene expression markers. A combination of the expression levels of several genes may provide a more robust tool, as different genes may be sensitive to different factors.

\section{Correlation between RNAseq and qPCR results}

The Ls A and Ls V lice from 2013 and the P0 generation were subjected to both RNAseq and qPCR analysis for the expression of catalase and Glp1_v2. The strength of the linear relationship (Pearson's correlation coefficient, $r$ ) between the two measurements were calculated to be $r_{(15)}=-0.917, P<0.0001$ and $r_{(15)}=-0.916, P<0.0001$, for catalase and Glp1_v2, respectively (Fig. 4). Both RNAseq analysis and qPCR analysis separated the groups similarly (Figs. 2, 3).

\section{$\mathrm{H}_{2} \mathrm{O}_{2}$ selection of resistant lice}

The $\mathrm{H}_{2} \mathrm{O}_{2}$-resistant strain (Ls V) was followed for five generations, of which three were $\mathrm{H}_{2} \mathrm{O}_{2}$-selected. The aims were to study if the resistant Ls V laboratory strain could further increase its resistance level and to study catalase expression after selection. Table 6 shows the percentage of affected lice after each $\mathrm{H}_{2} \mathrm{O}_{2}$ exposure. The $\mathrm{H}_{2} \mathrm{O}_{2}$ sensitivity was tested before selection and on the fifth generation (F5) of selected lice (Table 5). The $\mathrm{EC}_{50}$ for F5 males was similar to the value before selection $\left(\chi^{2}=1.27, d f=1\right.$, $P=0.259)$. The $\mathrm{EC}_{50}$ value for females increased slightly after selection (c.1.5 times), although this difference was not statistically significant $\left(\chi^{2}=2.11, d f=1, P=0.147\right)$. At the population level, the resistant Ls $\mathrm{V}$ laboratory strain may have increased its resistance only to a level similar to the field lice that originated the laboratory strain, which were exposed to $\mathrm{H}_{2} \mathrm{O}_{2}$ several times in the field (Table 5, Ls V F0). Thus, it could be possible that Ls V had reached its maximum level of tolerance.

Catalase expression was investigated in the $\mathrm{H}_{2} \mathrm{O}_{2}$-selected branch of the Ls $\mathrm{V}$ strain (F4 generation) and compared with Ls V-P0 lice (not exposed to $\mathrm{H}_{2} \mathrm{O}_{2}$ for two years). F4 lice were exposed twice to $\mathrm{H}_{2} \mathrm{O}_{2}$, as pre-adult I and pre-adult II (Table 6). When the females became adults, they were either exposed to $\mathrm{H}_{2} \mathrm{O}_{2}$ for a third time immediately before fixation or served as $\mathrm{H}_{2} \mathrm{O}_{2}$-selected control samples without $\mathrm{H}_{2} \mathrm{O}_{2}$ exposure during the adult stage. No differences in the expression levels of catalase were apparent between the three groups (statistical analysis could not be performed due to the low sample size in the groups, but the range of values overlapped; see Fig. 6).

The selection of resistant lice (Ls V) with $\mathrm{H}_{2} \mathrm{O}_{2}$ during three generations appears neither to increase significantly the resistance level of the population ( $\mathrm{EC}_{50}$ values),

Table $6 \mathrm{H}_{2} \mathrm{O}_{2}$ selection experiment of the $\mathrm{H}_{2} \mathrm{O}_{2}$-resistant strain Ls V: design and results (\% affected lice)

\begin{tabular}{|c|c|c|c|}
\hline $\mathrm{F}$ & $\mathrm{H}_{2} \mathrm{O}_{2}$ exposure data & Louse instar $(n)$ & $\%$ affected lice \\
\hline \multirow[t]{2}{*}{$\mathrm{F} 1$} & FBT (4): $1500 \mathrm{ppm}, 15-20 \mathrm{~min}, 11^{\circ} \mathrm{C}$ & Pre-adult I-II (250) & 8 \\
\hline & $\mathrm{BIO}: 2000 \mathrm{ppm}, 30 \mathrm{~min}, 11^{\circ} \mathrm{C}$ & Pre-adult II - adult males (180) & 33 \\
\hline \multirow[t]{2}{*}{$\mathrm{F} 2$} & FBT (4): $1500 \mathrm{ppm}, 15-20 \mathrm{~min}, 8.5^{\circ} \mathrm{C}$ & Pre-adult I-II (150) & 7 \\
\hline & $\mathrm{BIO}: 2500 \mathrm{ppm}, 30 \mathrm{~min}, 8.5^{\circ} \mathrm{C}$ & Pre-adult II - adult males (110) & 50 \\
\hline F3 & Not selected with $\mathrm{H}_{2} \mathrm{O}_{2}$ & - & - \\
\hline \multirow[t]{2}{*}{ F4 } & FBT (16): $1500 \mathrm{ppm}, 15-20 \mathrm{~min}, 8.5^{\circ} \mathrm{C}$ & Pre-adult I-II (360) & 8.3 \\
\hline & $\mathrm{BIO}: 2500 \mathrm{ppm}, 30 \mathrm{~min}, 11^{\circ} \mathrm{C}$ & Pre-adult II - adult males (312) & 63 \\
\hline F5 & Six-dose bioassay & Pre-adult II - adult males & - \\
\hline
\end{tabular}

Notes: F: lice generation (this F2 generation is not the same as the $\mathrm{F} 2$ generation from the crossing and RNAseq experiments). $\mathrm{H}_{2} \mathrm{O}_{2}$ exposure type and data: $\mathrm{FBT}$ (fish bath treatment), lice treated on-fish using a bath treatment methodology (number of fish used in parentheses); BIO (bioassay selection), lice treated off-fish using a bioassay methodology; $\mathrm{H}_{2} \mathrm{O}_{2}$ concentration, exposure time, water temperature. Instar: louse developmental stage; $n$ : number (approximately) of lice used in each selection event (males and females together) in parentheses. Selection on generation 3 (F3) could not be performed due to low lice numbers. F5 was not selected with $\mathrm{H}_{2} \mathrm{O}_{2}$; this generation was used to test the $\mathrm{H}_{2} \mathrm{O}_{2}$ sensitivity after selection using a six-dose bioassay (see bioassay details in Table 5) 


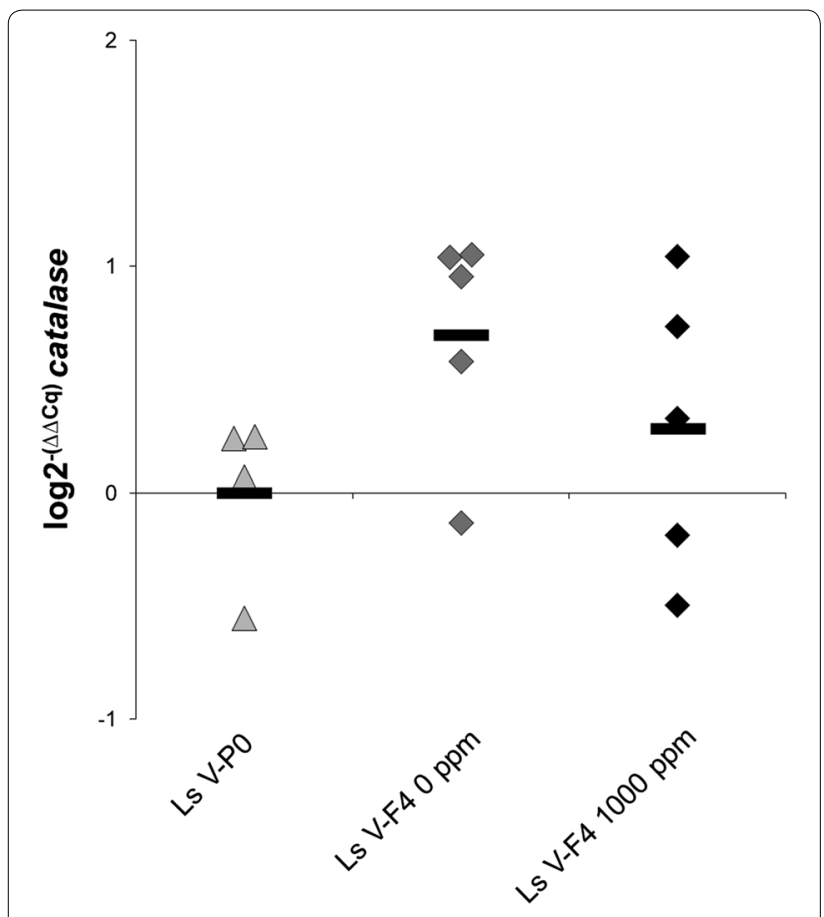

Fig. 6 qPCR study for catalase expression in $\mathrm{H}_{2} \mathrm{O}_{2}$-selected Ls $V$ lice (F4 generation; adult females) and in Ls V-PO lice from the RNAseq study: Ls V-P0 (grey triangles). Ls V-F4 0 ppm: selected Ls V lice not exposed to $\mathrm{H}_{2} \mathrm{O}_{2}$ before fixation (dark grey diamonds); Ls V-F4 1000 ppm: selected Ls V lice exposed to 1000 ppm $\mathrm{H}_{2} \mathrm{O}_{2}$ for 30 min immediately before fixation (black diamonds). Solid lines represent the arithmetic mean in each group. Data shown as fold change $\left(\log 2^{-(\Delta \Delta C q)}\right)$ referred to Ls V-PO lice (calibrator sample). Statistical analysis was not performed due to the low sample size in each group

nor to change catalase expression. Even though the $\mathrm{EC}_{50}$ values did not increase significantly, if the catalase induction hypothesis is correct, one would expect that the $\mathrm{H}_{2} \mathrm{O}_{2}$ exposure would change the expression of that gene in resistant parasites. However, a plausible explanation is that the selected lice were protected from the $\mathrm{H}_{2} \mathrm{O}_{2}$ exposure at the protein level, not needing to regulate the gene expression. It has been shown that the exposure of a shrimp species to a high concentration of $\mathrm{H}_{2} \mathrm{O}_{2}$ can induce catalase expression, whereas lower concentrations only alters catalase activity at the protein level [27]. Dawson \& Storey [42] showed that post-translational modifications of catalase could regulate the enzyme activity. Exposing resistant lice to 1000 ppm may be considered a "low" concentration for parasites that are able to survive $2500 \mathrm{ppm}$ (Table 6).

\section{Conclusions}

Catalase gene expression seems to be induced by $\mathrm{H}_{2} \mathrm{O}_{2}$ exposure. This may pose a challenge for its use as a sole biomarker for resistance, as a test should detect resistant parasites regardless of previous exposure history.
Moreover, the amount and activation state of the catalase protein cannot be discarded as part of the resistance mechanism, and lice may not need to modify the gene expression if they are protected at the protein level. The RNAseq study identified several genes differentially expressed when comparing resistant to sensitive lice, but most of them seemed related to a previous $\mathrm{H}_{2} \mathrm{O}_{2}$ exposure. However, five genes were consistently up- or downregulated in resistant lice independently of the $\mathrm{H}_{2} \mathrm{O}_{2}$ exposure, which make them potential good, complementary candidate genes for developing molecular markers for monitoring $\mathrm{H}_{2} \mathrm{O}_{2}$ resistance. The more promising one was Glp1_v2, an aquaglyceroporin, that was downregulated in all three groups of resistant lice. Since some aquaporins may serve as a passing channel for $\mathrm{H}_{2} \mathrm{O}_{2}$, lower protein number could reduce the influx or distribution of $\mathrm{H}_{2} \mathrm{O}_{2}$ in the salmon louse, being thus directly involved in the resistance mechanism.

\section{Supplementary information}

Supplementary information accompanies this paper at https://doi. org/10.1186/s13071-020-04211-1.

Additional file 1: Script S1. R-script to identify shared genes differentially expressed in the $\mathrm{H}_{2} \mathrm{O}_{2}$-resistant lice. Shared genes across all the groups (2013, P0 and F2) or between two of the groups (2013 vs P0; 2013 vs F2; and P0 vs F2), separately for up- and downregulated genes.

Additional file 2: Script S2. R-script to identify shared genes differentially expressed in the $\mathrm{H}_{2} \mathrm{O}_{2}$-resistant lice. Shared genes across all the groups (2013, P0 and F2) or between two of the groups (2013 vs P0; 2013 vs F2; and PO vs F2), separately for up- and downregulated genes.

Additional file 3: Dataset S1. Complete list of genes differentially expressed in the $\mathrm{H}_{2} \mathrm{O}_{2}$-resistant lice groups (Ls V-2013, Ls V-PO and Ls F2-R) versus the corresponding sensitive groups (Ls A-2013, Ls A-P0 and Ls F2-S), separately for up- and downregulated genes. Genes identified by their ENSEMBL entries. $P$ (adj): $P$-value for normalized counts $(a=0.05)$. Table S1. Genes upregulated in Ls V-2013 vs Ls A-2013. Table S2. Genes downregulated in Ls V-2013 vs Ls A-2013.Table S3. Genes upregulated in Ls V-PO vs Ls A-P0. Table S4. Genes downregulated in Ls V-PO vs Ls A-P0. Table S5. Genes upregulated in Ls F2-R vs Ls F2-S. Table S6. Genes downregulated in Ls F2-R vs LS F2-S.

Additional file 4: Dataset S2. Genes differentially expressed shared between $\mathrm{H}_{2} \mathrm{O}_{2}$-resistant lice, separately for up- and downregulated genes. Genes identified by their ENSEMBL entries. Table S1. Shared genes downregulated between two resistant groups: 2013 vs P0, 2013 vs F2 or P0 vs F2. Table S2. Shared genes downregulated across all the resistant groups: 2013, P0 and F2. Table S3. Shared genes upregulated between two resistant groups: 2013 vs P0, 2013 vs F2 or P0 vs F2. Table S4. Shared genes upregulated across all the resistant groups: 2013, P0 and F2.

\section{Abbreviations}

CDNA: complementary DNA; Cl: confidence interval; EC $_{50}$ : compound concentration affecting $50 \%$ of the parasites; ERP29: endoplasmic reticulum resident protein 29; Fx: generation of lice; F2: second generation after crossing of Ls A and Ls V lice strains; Glp1_v2, Aqp12L1, Aqp12L2, Glp2, Glp3_v1: several aquaporin types; $\mathrm{H}_{2} \mathrm{O}_{2}$ : hydrogen peroxide; Ls A: sensitive Lepeophtheirus salmonis strain; Ls V: resistant Lepeophtheirus salmonis strain; ppm: parts per million; NA: unannotated protein; qPCR: quantitative polymerase chain reaction; RNA: ribonucleic acid; RNAseq: RNA sequencing. 


\section{Acknowledgements}

The authors would like to thank Cristina de Castro Garcia and Daniela Dulgheriu for their technical help in the molecular work, Melanie Andrews for proofreading the manuscript, and Lars A. Hamre and Per Gunnar Espedal from the University of Bergen for their valuable help in cultivating the salmon lice for the selection experiment. We sincerely thank the comments and suggestions made by the anonymous reviewers which improved the manuscript.

\section{Authors' contributions}

CAR, TEH and MJB were involved in the planning of the study, interpretation of the results and in writing the manuscript. CAR performed most of the louse sampling, bioassays, selection experiment and molecular analysis, including the RNAseq study. $\mathrm{KOH}$ and $\mathrm{KK}$ contributed in the louse crossing experiment and the RNAseq study. SJB contributed in some analysis of the RNAseq study. AYMS and TEH performed most of the bioinformatic analysis in the RNAseq study. All authors read and approved the final manuscript.

\section{Funding}

This study was financed by the innovation project "Resistance to hydrogen peroxide in salmon lice (Lepeophtheirus salmonis)" (NFR 245373/E40) and the SFI-Sea Lice Research Centre (NFR 203513/O30), which are both financed by The Research Council of Norway.

\section{Availability of data and materials}

The datasets generated and analyzed during the current study are available in the Sequence Read Archive (SRA) repository, NCBI, PRJNA636941, http://www. ncbi.nlm.nih.gov/bioproject/636941.

\section{Ethics approval and consent to participate}

The use of fish for salmon lice cultivation was approved by the Norwegian Food Safety Authorities according to the Norwegian Animal Welfare Act (LovData; LOV-2009-06-19-97) and Regulations for the Use of Research Animals (LovData; FOR-2015-06-18-761).

\section{Consent for publication}

Not applicable.

\section{Competing interests}

The authors declare that they have no competing interests.

\section{Author details}

${ }^{1}$ Faculty of Veterinary Medicine, Sea Lice Research Centre, Norwegian University of Life Sciences, 1433 Aas, Norway. ${ }^{2}$ Department of Epidemiology, Norwegian Veterinary Institute, Pb. 750 Sentrum, 0106 Oslo, Norway. ${ }^{3}$ Department of Medical Genetics, Oslo University Hospital, 0450 Oslo, Norway. ${ }^{4}$ Department of Geosciences, The Faculty of Mathematics and Natural Sciences, University of Oslo, 0371 Oslo, Norway. ${ }^{5}$ Aker Biomarine Antarctic AS, P.O. Box 496, 1327 Lysaker, Norway.

Received: 9 April 2020 Accepted: 2 July 2020

Published online: 10 July 2020

\section{References}

1. Aaen SM, Helgesen KO, Bakke MJ, Kaur K, Horsberg TE. Drug resistance in sea lice: a threat to salmonid aquaculture. Trends Parasitol. 2015;31:72-81.

2. Cerbule K, Godfroid J. Salmon louse (Lepeophtheirus salmonis (Krøyer)) control methods and efficacy in Atlantic salmon (Salmo salar (Linnaeus)) aquaculture: a literature review. Fishes. 2020;5:11.

3. Torrissen O, Jones S, Asche F, Guttormsen A, Skilbrei OT, Nilsen F, et al. Salmon lice - impact on wild salmonids and salmon aquaculture. J Fish Dis. 2013;36:171-94.

4. Fiskehelserapporten-2019. https://www.vetinst.no/rapporter-og-publi kasjoner/rapporter/2020/fiskehelserapporten-2019. Accessed 2 Apr 2020.

5. Resistensovervåkningsrapporten-2019. https://www.vetinst.no/overv aking/lakselus-resistens. Accessed 2 Apr 2020.

6. Barentswatch. https://www.barentswatch.no/fiskehelse/. Accessed 2 Apr 2020 .
7. Grave K, Horsberg TE, Lunestad BT, Litleskare I. Consumption of drugs for sea lice infestations in Norwegian fish farms: methods for assessment of treatment patterns and treatment rate. Dis Aquat Organ. 2004;60:123-31.

8. Norwegian Institute of Public Health-2014. https://www.fhi.no/hn/legem iddelbruk/fisk/forbruket-av-lakselusmidler-er-hoyt/ Accessed 2 Apr 2020.

9. Powell MD, Reynolds P, Kristensen T. Freshwater treatment of amoebic gill disease and sea-lice in seawater salmon production: considerations of water chemistry and fish welfare in Norway. Aquaculture. 2015;448:18-28.

10. Norwegian Institute of Public Health-2019. https://www.fhi.no/hn/legem iddelbruk/fisk/2019-bruk-av-legemidler-i-fiskeoppdrett/. Accessed 18 May 2020.

11. Helgesen $\mathrm{KO}$, Romstad $\mathrm{H}$, Aaen SM, Horsberg TE. First report of reduced sensitivity towards hydrogen peroxide found in the salmon louse Lepeophtheirus salmonis in Norway. Aquac Rep. 2015;1:37-42.

12. Treasurer JW, Wadsworth S, Grant A. Resistance of sea lice, Lepeophtheirus salmonis (Kroyer), to hydrogen peroxide on farmed Atlantic salmon, Salmo salar L. Aquac Res. 2000;31:855-60.

13. Veal EA, Day AM, Morgan BA. Hydrogen peroxide sensing and signalling. Mol Cell. 2007;26:1-14.

14. Helgesen KO, Bakke MJ, Kaur K, Horsberg TE. Increased catalase activitya possible resistance mechanism in hydrogen peroxide resistant salmon lice (Lepeophtheirus salmonis). Aquaculture. 2017:468:135-40.

15. Kaur K, Horsberg TE, Helgesen KO. Method for detecting $\mathrm{H}_{2} \mathrm{O}_{2}$ resistance in crustaceans. Patent application WO2016001295A1. 2016. Priority date 22.12.2014. https://patentimages.storage.googleapis.com/1d/ e6/49/5cf5b226832b64/WO2016001295A1.pdf. Accessed 2 Apr 2020.

16. Kaur K, Jansen PA, Aspehaug VT, Horsberg TE. Phe362Tyr in AChE: a major factor responsible for azamethiphos resistance in Lepeophtheirus salmonis in Norway. PLoS ONE. 2016;11:e0149264.

17. Jansen PA, Grøntvedt RN, Tarpai A, Helgesen KO, Horsberg TE. Surveillance of the sensitivity towards antiparasitic bath-treatments in the salmon louse (Lepeophtheirus salmonis). PLoS ONE. 2016;11:e0149006.

18. Hamre LA, Glover KA, Nilsen F. Establishment and characterisation of salmon louse (Lepeophtheirus salmonis (Kroyer 1837)) laboratory strains. Parasitol Int. 2009;58:451-60.

19. Bakke MJ, Agusti C, Bruusgaard JC, Sundaram AYM, Horsberg TE. Deltamethrin resistance in the salmon louse, Lepeophtheirus salmonis (Krøyer): maternal inheritance and reduced apoptosis. Sci Rep. 2018;8:8450.

20. Bolger AM, Lohse M, Usadel B. Trimmomatic: a flexible trimmer for Illumina sequence data. Bioinformatics. 2014;30:2114-20.

21. Kim D, Langmead B, Salzberg SL. HISAT: a fast spliced aligner with low memory requirements. Nat Methods. 2015;12:357-60.

22. Stavang JA, Chauvigné F, Kongshaug H, Cerdà J, Nilsen F, Finn RN. Phylogenomic and functional analyses of salmon lice aquaporins uncover the molecular diversity of the superfamily in Arthropoda. BMC Genomics. 2015;16:618.

23. Li H, Handsaker B, Wysoker A, Fennell T, Ruan J, Homer N, 1000 Genome Project Data Processing Subgroup, et al. The sequence alignment/map format and SAMtools. Bioinformatics. 2009;25:2078-9.

24. Trapnell C, Williams BA, Pertea G, Mortazavi A, Kwan G, van-Baren MJ, et al. Transcript assembly and quantification by RNA-seq reveals unannotated transcripts and isoform switching during cell differentiation. Nat Biotechnol. 2010;28:511-5.

25. Liao Y, Smyth GK, Shi W. FeatureCounts: an efficient general purpose program for assigning sequence reads to genomic features. Bioinformatics. 2014;30:923-30

26. Love MI, Huber W, Anders S. Moderated estimation of fold change and dispersion for RNA-seq data with DESeq2. Genome Biol. 2014;15:550.

27. Wang D, Li F, Chi Y, Xiang J. Potential relationship among three antioxidant enzymes in eliminating hydrogen peroxide in penaeid shrimp. Cell Stress Chaperon. 2012;17:423-33.

28. Su M, Ling Y, Yu J, Wu J, Xiao J. Small proteins: untapped area of potential biological importance. Front Genet. 2013;4:286.

29. Bhati KK, Blaakmeer A, Botterweg-Paredes E, Dolde U, Eguen T, Hong SY, et al. Approaches to identify and characterize microProteins and their potential uses in biotechnology. Cell Mol Life Sci. 2018;75:2529-36.

30. Bienert GP, Møller AL, Kristiansen KA, Schulz A, Møller IM, Schjoerring JK, et al. Specific aquaporins facilitate the diffusion of hydrogen peroxide across membranes. J Biol Chem. 2007;282:1183-92. 
31. Herrera M, Garvin JL. Aquaporins as gas channels. Pflugers Arch Eur J Physiol. 2011:462:623.

32. Miller EW, Dickinson BC, Chang CJ. Aquaporin-3 mediates hydrogen peroxide uptake to regulate downstream intracellular signaling. Proc Natl Acad Sci USA. 2010;107:15681-6.

33. Thiagarajah JR, Chang J, Goettel JA, Verkman AS, Lencer WI. Aquaporin3-mediated colonic epithelial responses. Proc Natl Acad Sci USA. 2017; 114:568-73.

34. Zwiazek JJ, Xu H, Tan X, Navarro-Ródenas A, Morte A. Significance of oxygen transport through aquaporins. Sci Rep. 2017;7:40411.

35. Song J, Mak E, Wu B, Beitz E. Parasite aquaporins: current developments in drug facilitation and resistance. Biochim Biophys Acta. 2014;1840:1566-73.

36. Faghiri Z, Skelly PJ. The role of tegumental aquaporin from the human parasitic worm, Schistosoma mansoni, in osmoregulation and drug uptake. FASEB J. 2009;23:2780-9.

37. Mandal G, Orta JF, Sharma M, Mukhopadhyay R. Trypanosomatid Aquaporins: roles in physiology and drug response. Diseases. 2014;2:3-23.

38. Gourbal B, Sonuc N, Bhattacharjee H, Legare D, Sundar S, Ouellette M, et al. Drug uptake and modulation of drug resistance in Leishmania by an aquaglyceroporin. J Biol Chem. 2004;279:31010-7.
39. Marquis N, Gourbal B, Rosen BP, Mukhopadhyay R, Ouellette M. Modulation in aquaglyceroporin AQP1 gene transcript levels in drug-resistant Leishmania. Mol Microbiol. 2005;57:1690-9.

40. Baker N, Glover L, Munday JC, Andres DA, Barrett MP, de Koning $\mathrm{HP}$, et al. Aquaglyceroporin 2 controls susceptibility to melarsoprol and pentamidine in African trypanosomes. Proc Natl Acad Sci USA. 2012;109:10996-1001.

41. Mandal G, Sharma M, Kruse M, Sander-Juelch C, Munro LA, Wang Y, et al. Modulation of Leishmania major aquaglyceroporin activity by a mitogenactivated protein kinase. Mol Microbiol. 2012;85:1204-18.

42. Dawson NJ, Storey KB. A hydrogen peroxide safety valve: the reversible phosphorylation of catalase from the freeze-tolerant North American wood frog, Rana sylvatica. Biochim Biophys Acta. 2016;1860:476-85.

\section{Publisher's Note}

Springer Nature remains neutral with regard to jurisdictional claims in published maps and institutional affiliations.
Ready to submit your research? Choose BMC and benefit from:

- fast, convenient online submission

- thorough peer review by experienced researchers in your field

- rapid publication on acceptance

- support for research data, including large and complex data types

- gold Open Access which fosters wider collaboration and increased citations

- maximum visibility for your research: over $100 \mathrm{M}$ website views per year

At BMC, research is always in progress.

Learn more biomedcentral.com/submissions 